\title{
AS MULHERES NA VITA SANCTI AEMILIANI E NA LEGENDA BEATI PETRI GUNDISALVI: UM ESTUDO DE COMPARAÇÃO DIACRÔNICA
}

\section{Women in Vita Sancti Aemiliani and in the Legend Beati Petri Gundisalvi: a diachronic comparison study}

\begin{abstract}
Prof. Dra. Dra. Andréia Cristina Lopes Frazão da Silva (Coordenadora do Pem-UFRJ) Programa de Estudos Medievais - Universidade Federal do Rio de Janeiro (PPGHC) ORCID: https://orcid.org/0000-0003-0210-1166 andreiafrazao@terra.com.br

Prof. Dra. Leila Rodrigues da Silva (Coordenadora do Pem - UFRJ) Programa de Estudos Medievais - Universidade Federal do Rio de Janeiro (PPGHC) leila.rlk@terra.com.br ORCID: https://orcid.org/0000-0002-5666-7280
\end{abstract}

\begin{abstract}
Resumo : A historiografia tem discutido as múltiplas funções da hagiografia, além da própria sistematização e registro das memórias de santidade vinculadas a um santo. Os estudos que analisam os textos hagiográficos em geral, e, em particular as vidas de santos, têm apontado como tais materiais promovem o cristianismo, com ênfase em ideias e valores consoantes a cada período histórico.

Nesse artigo, elegemos como objeto de análise as mulheres no medievo ibérico. Para o desenvolvimento de nossas reflexões, partimos de duas obras que relatam a trajetória de dois santos: a Vita Sancti Aemiliani, elaborada no século VII, e a Legenda Beati Petri Gundisalvi, composta no século XIII. Nesse sentido, propomos uma discussão sobre a inserção social dos eclesiásticos e o papel das mulheres no medievo peninsular. Para tal realizamos um exercício comparativo em perspectiva diacrônica, inspiradas em algumas das reflexões de Paul Veyne.
\end{abstract}

Palavras-chave: hagiografia; mulheres; comparação; Península Ibérica medieval

Abstract : Historiography has discussed the multiple functions of hagiography, in addition to the systematization and recording of memories of holiness linked to a saint. Studies that analyze hagiographic texts in general, and, in particular, the lives of saints, have pointed out how such materials promote Christianity, with an emphasis on ideas and values consistent with each historical period.

In this article, we chose women in the Iberian medieval period as the object of analysis. For the development of our reflections, we started from two works that relate the trajectory of two saints: the Vita Sancti Aemiliani, elaborated in the 7th century, and the Legend Beati Petri Gundisalvi, composed in the 13th century. In this sense, we propose a discussion on the social insertion of ecclesiastics and the role of women in the medieval peninsular. To this end, we carried out a comparative exercise in a diachronic perspective, inspired by some of Paul Veyne's reflections.

Keywords: Historiography; Women; Comparation; Medieval Iberian Peninsula 


\section{Considerações introdutórias}

A historiografia tem discutido as múltiplas funções da hagiografia, ${ }^{1}$ além da própria sistematização e registro das memórias de santidade vinculadas a um santo. Os estudos que analisam os textos hagiográficos em geral, e, em particular as vidas de santos, ${ }^{2}$ têm apontado como tais materiais promovem o cristianismo, com ênfase em ideias e valores consoantes a cada período histórico; apresentam modelos de comportamento; distinguem grupos sociais específicos e desqualificam oponentes; reafirmam a relação do santo com espaços e modos de vida; buscam atrair peregrinos e ofertas, etc. Neste sentido, esses textos têm sido empregados em pesquisas que se detêm em diferentes objetos, tais como a pobreza; a educação; a morte, a alimentação, para citar alguns exemplos. ${ }^{3}$

Nesse artigo, elegemos como objeto as mulheres no medievo ibérico. ${ }^{4}$ Para o desenvolvimento de nossas reflexões privilegiamos duas obras que relatam a trajetória de dois santos: a Vita Sancti Aemiliani, elaborada no século VII, e a Legenda Beati Petri Gundisalvi, composta no século XIII. Partimos de algumas questões: quais mulheres figuram em tais obras? Em quais situações? Como elas se conectam, no âmbito narrativo, com os santos protagonistas? Há especificidades e/ou confluências nas relações estabelecidas entre os santos e as mulheres em cada obra analisada? Como explicá-las? O que o estudo de tais relações permite afirmar sobre a inserção social dos eclesiásticos e o papel das mulheres no medievo peninsular? ${ }^{5}$

Para responder a tais questões realizamos um exercício comparativo em perspectiva diacrônica. Inspiradas em algumas das reflexões de Paul Veyne (1983), ${ }^{6}$ a partir de uma constante - mulher - analisamos as duas hagiografias selecionadas, que, como já assinalado, foram produzidas no mesmo espaço - a Península Ibérica -, mas em conjunturas diversas: uma no âmbito do reino visigodo e a outra no reino castelhano. A partir desse elemento variável - momento de redação - realizamos a comparação a fim de elaborarmos um inventário de diferenças e semelhanças, que foram analisadas à luz do contexto de produção de cada uma das obras, sem perder de vista os elementos de permanência.

Considerando que os textos hagiográficos são narrativas, ${ }^{7}$ para o levantamento dos dados que foram estudados, analisamos os trechos das obras nos quais há 
referências a mulheres, com o objetivo de discutir os sentidos construídos nos relatos. Desta forma, buscamos identificar se as mulheres são citadas ou atuam como personagens na trama; se são somente referenciadas, observamos em qual contexto são mencionadas, se são personagens ativas, como são caracterizadas e agem no decorrer da trama. Também nos detivemos em outros elementos, tais como intervalos de tempo e espaços nos quais as ações se desenvolvem; a trama; a presença de um narrador, dentre outros.

É o resultado deste trabalho comparativo e analítico, relacionado aos projetos Modalidades de vida religiosa e relações de poder: estudo comparado de hagiografias medievais (séculos VI-XIII) ${ }^{8}$ e A construção medieval da memória de santos venerados na cidade do Rio de Janeiro: uma análise a partir da categoria gênero, ${ }^{9}$ financiados pela FAPERJ, que apresentamos nesse artigo.

\section{A Vita Sancti Aemiliani ${ }^{10}$}

A partir de fins do século VI, após a conversão de Recaredo ao cristianismo niceno, intensificou-se o processo de reorganização da instituição eclesiástica no reino visigodo, visando à expansão da fé e ao fortalecimento das estruturas clericais. Embora as condições locais em cada região do reino pudessem variar muito em relação às dificuldades a serem superadas, de um modo geral, verifica-se um amplo envolvimento do episcopado hispânico. Como parte dessa atuação, um rico conjunto de escritos foi formulado, compreendendo, dentre outros, atas conciliares, sermões, regras monásticas, compêndios, manuais e hagiografias. Seja atendendo a objetivos específicos dentro daquele processo, seja em conformidade com motivações mais amplas, o volume de textos produzido se diferenciou muito em cada um dos tipos.

Assim, se foram escritas e preservadas, por exemplo, uma quantidade significativa de atas conciliares, o mesmo fenômeno não se observa em relação aos registros hagiográficos. Diferentemente de outras regiões, como nas Gálias, foram poucas as hagiografias concebidas na Península Hispânica nos séculos VI e VII. Desse restrito conjunto interessa-nos, conforme anunciado anteriormente, analisar a VSA com o foco nos sentidos construídos acerca das referências às mulheres. 
A Vita Sancti Aemiliani alcançou considerável prestígio na Idade Média graças à sua inclusão na Compilação de Valério do Bierzo que, de acordo com Díaz y Díaz (1951: 22), pode ser considerada uma das mais importantes obras do período visigodo, tendo circulado consideravelmente nos meios monásticos (DÍAZ Y DÍAZ, 1951: 6). Dos códices que contêm partes da compilação valeriana, o datado de princípios do século $\mathrm{X}$, pertencente à Biblioteca de Madrid e conhecido como T, reúne o maior e mais antigo conjunto. Partes menores e complementares da compilação também estão no denominado códice M, dos séculos IX-X, da Real Academia de História de Madrid; nos manuscritos 822, identificado como códice N, e no 494, conhecido como B, ambos da Biblioteca Nacional de Madrid, e no códice S, oriundo de Silos, guardado na Biblioteca Nacional de Paris (acq. lat., manuscrito 2178) (DÍAZ Y DÍAZ, 1951: 4-8). Segundo Valcárcel, a Vita Aemilini estaria conservada sobretudo em manuscritos que contêm legendários. Assim, além do antes indicado, assinala a presença em Lisboa, na Biblioteca Nacional de Portugal, Alcobaça 454, e em Salamanca, na Biblioteca da Universidade, manuscrito 2537 (VALCÁRCEL, 1997: 401, nota 93). A Vita Sancti Aemiliani foi publicada no volume 80 da Patrologia Latina, em fins do século XIX (PL, 80, 699-714), e teve sua primeira edição crítica em 1943, sob a responsabilidade de Luis Vázquez de Parga. O texto está registrado na Bibliotheca hagiographica latina antiquae et medice cetatis sob o número 100.

O documento apresenta a vida de Emiliano, que teria nascido na região norte da Península Hispânica, especificamente no entorno de Berceo, entre os anos de 470 e 473. Identificado, quando muito jovem, como pastor de ovelhas, suas origens familiares são indicadas como humildes (LOMAS SALMONTE, 1998: 255-256). Caracterizado predominantemente como eremita, nos moldes dos Padres do Deserto, é descrito como exemplo de ascetismo e apego ao isolamento. Assim, após se converter aos vinte anos e receber orientações de um anacoreta local, teria vivido sozinho em áreas de difícil acesso e condições pouco acolhedoras por quase quarenta anos. Sua conduta santa, entretanto, teria atraído a atenção de fieis e das autoridades clericais. O bispo local teria lhe ordenado e designado como sacerdote, função que teria exercido por pouco tempo, já que fora denunciado pelos membros da comunidade por distribuir os bens da instituição que, em tese, deveria preservar. Sua longa vida teria sido marcada por uma grande quantidade de milagres, envolvendo personagens da comunidade e das 
imediações. Já com a idade avançada teria sido cuidado em ambiente comunitário feminino por religiosas locais até o ano de 574, quando sua morte é registrada (VALCÁRCEL, 1997: 380).

Composta entre 635 e 640 (VALCÁRCEL, 1997: 379) por Bráulio, bispo de Saragoça, trata-se de um escrito de cuja autoria não se tem dúvidas. $\mathrm{O}$ autor fornece no prólogo do texto várias informações sobre sua família, incluindo o destinatário do relato, seu irmão Frominiano, abade em La Rioja. Nascido entre 581 e 600 (LYNCH; GALINDO, 1950: 20), Bráulio assumiu o bispado em 631, quando sucedeu seu irmão mais velho, João, após a morte. Sua família contou ainda com outras destacadas figuras vinculadas à instituição eclesiástica, como seu pai, Gregório, que foi bispo de Osma; sua irmã, a abadessa Pompônia, além de Frominiano, antes referido. A obra teria sido produzida a pedido do seu antecessor e a demanda teria sido mantida por Fromimiano, conforme a dedicatória que lhe faz Bráulio.

Ainda que, considerando os propósitos deste artigo, não interesse discutir a historicidade do hagiografado, parece-nos oportuno assinalar que o texto produzido por Bráulio é o único registro sobre a existência do santo. Apesar deste dado, tendo em vista o pequeno intervalo entre a data de morte que lhe foi atribuída e a redação do texto (VALCÁRCEL, 1997: 390), assim como a referência nominal a testemunhos de sua santidade, pode-se considerar que na região, em fins do século $\mathrm{V}$, alguém bastante respeitado e admirado exerceu forte influência sobre as populações.

Essa possibilidade vai ao encontro dos argumentos que salientam o envolvimento de Bráulio e sua família com o culto do santo. ${ }^{11}$ Assim, há consenso entre os especialistas de que a família de Bráulio possuía interesse em capitalizar o culto de Emiliano (MIGUEL FRANCO, 2015: 25-26), o que fortaleceria seu prestígio junto às demais famílias aristocráticas na região nordeste da Península e às populações menos privilegiadas do entorno do Alto Ebro (SANTIAGO CASTELLANOS, 2004: 289-296). Em outras palavras, o interesse dos três irmãos em um registro hagiográfico de um homem influente localmente, morto há poucas décadas, vinculava-se ao conhecido fenômeno da promoção de cultos e dos benefícios aos seus promotores.

Embora existam dúvidas sobre onde teria se dado a formação do autor, é certo que cumpriu todas as etapas de estudos reservadas à elite hispanoromana. Conforme a introdução da VSA, estudou inicialmente sob a tutela dos seus irmãos mais velhos. A 
posterior ida para Sevilha, onde teria sido discípulo de Isidoro de Sevilha, ainda que indicada por autores como Lynch e Galindo (1950: 28-31), não se reconhece mais como certa (MIGUEL FRANCO, 2015: 23-25). As recentes análises da correspondência trocada com o Sevilhano concluíram por uma relação entre os dois posterior ao período de estudos de Bráulio (MIGUEL FRANCO, 2015: 21-23). Independentemente de onde tenha concluído sua formação, reconhece-se a sua grande erudição, ao que, inclusive se associa sua correspondência e atuação nos concílios de Toledo, IV, V e VI, realizados entre os anos de 633 e 638, o trabalho de revisão da Lex Visigothorum (ORTIZ DE GUINEA, 1994: 164) e provavelmente também das Etimologias (LYNCH; GALINDO, 1950: 64), escrita por Isidoro. É certo, pois, que Bráulio estava bastante ciente do papel que a hagiografia de Emiliano poderia assumir como mecanismo de projeção ideológica dos grupos nobiliárquicos aos quais sua família pertencia (SANTIAGO CASTELLANOS, 2004: 263).

O texto produzido por Bráulio exibe um narrador que tem pleno conhecimento das ações que deseja realçar, não obstante, utilize-se de topoi ressaltando a relevância de testemunhos e a sua impossibilidade de descrever com a máxima propriedade o percurso do eremita. A hagiografia contém os elementos fundamentais da maioria das vidas de santos produzidas no período, com referências ao ascetismo de Emiliano, à sua conversão, à realização de milagres, ao prenúncio de sua morte e à sua atuação postmortem. Do ponto de vista cronológico, o autor estabelece as balizas essenciais, conversão e morte, e se dedica prioritariamente à exposição dos muitos milagres do santo. Tal opção favorece uma narrativa flexível, ou seja, não há conexão sequencial entre a maioria dos eventos, permitindo, portanto, que o autor estabeleça blocos temáticos. Reúne, assim, sucessões de episódios compreendendo, dentre outros, milagres de cura, milagres relacionados ao diabo, milagres relacionados à elite.

A obra pode ser dividida em dois blocos: um, constituído por uma carta de apresentação ao irmão Frominiano, e outro, composto por um prefácio e trinta e um capítulos (BRAULIO OF SARAGOSSA, 1977: 15-43). No primeiro deles, além das já mencionadas informações sobre sua família e explicações sobre a demora para redigir o material solicitado pelos irmãos, Bráulio justifica a utilização da linguagem singela e clara que adotará ao tratar da vida do santo. Conforme seu argumento, isso facilitará a compreensão do texto ao ser lido na celebração da missa. Apesar de sua ressalva, o 
público a que se destina não se restringe aos ouvintes predominantemente locais e de origens simples. A alusão nas primeiras linhas da carta a integrantes da elite local, como a Potâmia, ${ }^{12}$ uma das responsáveis por atestar a santidade de Emiliano, sugere, assim como os milagres envolvendo a elite local, a intenção de que a hagiografia circulasse entre os variados segmentos sociais. É igualmente provável que o público pretendido incluísse o ambiente episcopal peninsular. Não por acaso, a VSA é mencionada em dois importantes registros: em uma carta de Frutuoso, bispo de Dume e Braga, a Bráulio, na qual demanda cópia da obra (EPISTOLÁRIO, 1975: 164-166), e em referência explícita ao legado de Bráulio, no De Viris Ilustribus de Ildefonso de Toledo (El De Viris Illustribus, 1972: 130).

No segundo, está reunida toda a trajetória do santo da conversão à morte, contendo situações diversas, com ilustrações de passagens bíblicas e descrição de milagres. Dos trinta e um capítulos, seis apresentam aspectos distintos da sua vida, seguidos por dezesseis que narram feitos milagrosos, quatro focando adversidades e premonições, um relatando sua morte e mais quatro referentes aos milagres postmortem. Neste conjunto, estão identificadas nove referências a figuras femininas, compreendendo temáticas variadas. Vejamos uma a uma as referidas situações.

\section{As mulheres na Vita Sancti Aemiliani}

A primeira das menções está registrada ainda no prefácio da obra e indica o cuidado, já reportado, de que a elite local se identificasse com o texto. Aos três eclesiásticos apontados por Bráulio como testemunhas da santidade de Emiliano, somou-se o nome de Potâmia que, além de pertencer ao universo religioso feminino, provinha de linhagem nobre da região. Ainda que caracterizada como religiosa capaz de asseverar os feitos de Emiliano, ${ }^{13}$ ou seja, prestigiosamente referida, compartilha com três homens a distinção. Em meio a um processo de expansão do cristianismo, objetivo ao qual a circulação de hagiografias está diretamente associada no período, é possível que a inclusão de Potâmia no ilustre rol de testemunhas atendesse à preocupação em atrair a simpatia das mulheres do entorno e do seu meio social.

É certo, entretanto, que Bráulio não a indicou como testemunha única ou mesmo buscou equilibrar aquela lista com igual número de homens e mulheres. De um modo 
geral, no período, enquanto abundam nomes masculinos entre os dignos de nota nos escritos episcopais, raras vezes as figuras femininas são destacadas. No que concerne aos textos hagiográficos produzidos no reino visigodo, por exemplo, além de Potâmia, o mesmo status é conferido apenas à Benedicta, na Vitae Sancti Fructuosi (1974: c.16-17, 107-111). Sua referência por Bráulio parece ter repercutido de tal modo que não se pode excluir a possibilidade de que esta tenha sido a principal motivação para que, séculos depois, uma vida, ainda que muito curta, fosse-lhe dedicada (FEROTIN, 1902: p. 40).

A segunda mulher mencionada na VSA é nomeada, assim como Potâmia, e identificada quanto à sua procedência geográfica. Após uma sucessão de citações genéricas aos feitos de Emiliano, a partir do capítulo 7, o hagiógrafo passa a descrever com mais detalhes a atuação milagrosa do santo. Desse modo, no capítulo 9, Bárbara é a primeira das mulheres a se beneficiar com sua ação. Procedente de Amaia, ao que tudo indica, região conhecida do público em potencial da hagiografia, mas suficientemente distante para que o autor a destacasse, ${ }^{14}$ a mulher teria sido levada ao santo para que a curasse de uma paralisia. Após a oração de Emiliano, o restabelecimento ocorreu de imediato. A passagem inaugura uma breve sucessão de referências às mulheres beneficiadas com curas.

No capítulo seguinte, ao descrever o próximo milagre, o autor destaca que a contemplada procedia do mesmo território que Bárbara. Assim como ela, a mulher foi levada até a presença do santo. Desejando ressaltar sua doença, sublinha que o deslocamento havia sido feito com o auxílio de algum meio de transporte, já que se tratava de uma pessoa que não podia se apoiar nos próprios pés. Sem que seu nome fosse identificado, o milagre da cura só se realizou devido a insistência da mulher. De acordo com a narrativa, Emiliano dedicado às orações da Quaresma desejava ficar isolado, mas cedeu diante dos muitos pedidos da fiel anônima que obteve cura imediata tão logo pode estar com o santo. Sua gratidão é destacada, assim como a sua demonstração de fé.

A próxima favorecida também não está identificada pelo nome, mas pela função que ocupa junto ao senador Sicório e por sua enfermidade. Na curtíssima passagem, destacam-se, além da referência a um integrante da elite local, o fato de que o santo teria operado o milagre por meio de orações e após o toque em seus olhos. Embora a alusão ao senador aparentemente apenas sirva para identificar a beneficiada, acaba por também 
evidenciar a intenção do autor em sublinhar o círculo de convívio do santo, que não se restringia às pessoas simples. Logo, cabe ressaltar que, embora os três milagres identificados na sequência não façam menção a mulheres, recaindo sobre um diácono (c. 12) e mais dois servos (c. 13 e 14), cujos senhores são nominalmente referidos Tuêncio e o conde Eugênio -, reforçam a amplitude social das relações estabelecidas pelo hagiografado.

No capítulo 15, mais uma vez, a alusão simultânea a uma mulher e à elite local é realizada. Diferentemente do bloco anterior, que havia destacado a cura de enfermidades, observa-se aqui um subconjunto em que a possessão é a motivação para a ação do santo. Neste capítulo, o senador Nepociano e sua esposa, Proséria, são descritos como possuídos pelo demônio. Ambos estariam doentes em função da intervenção demoníaca, o que, de acordo com a narrativa, era do conhecimento de todos da região da Cantábria. Levados ao santo, a expulsão do inimigo teria ocorrido causando o contentamento e o reconhecimento do poder divino por ambos.

Não há qualquer peculiaridade na referência à Proséria que indicasse um tratamento diferente do conferido ao seu marido. Ao contrário das mulheres antes mencionadas, figura como personagem acoplada a um homem. Sua indistinção é de tal ordem que, de acordo com o relato, "um só demônio habitaria os dois corpos", ou seja, não possui sequer um pleito específico a apresentar ao santo. ${ }^{15}$ Sua menção parece, pois, apenas reforçar a intenção do autor em destacar o reconhecimento da santidade de Emiliano pelo maior número possível de integrantes da elite local.

No capítulo 16, descreve-se mais um caso envolvendo uma mulher pertencente à elite vitimada de possessão. Columba, a filha do curial Máximo, sofrendo de espasmos decorrentes da ação demoníaca, foi levada à presença de Emiliano que, atendendo ao seu desejo e às esperanças de cura, realiza o sinal da cruz e expulsa o invasor. Milagres associados à presença do demônio são registrados em quatro outras situações (c. 12, 13, 14 e 17), nestes casos, entretanto, não há participação ou referência a mulheres. Cabe, pois, indicar que tais episódios não possuem elementos que os distingam substancialmente da situação experimentada por Columba, com exceção da singular descrição realizada no capítulo 17. Nesta passagem, o demônio se apoderou de uma residência e não de uma pessoa. 
No desenrolar da narrativa hagiográfica, novas referências envolvendo a cura de mulheres são atestadas. Ambas estão registradas dentre os quatro milagres realizados pelo santo post-mortem. No primeiro deles (c. 30), uma mulher chamada Eufrísia, coxa e cega, e muito certa de sua fé, teria sido curada no túmulo do santo. De acordo com o relato, Eufrísia procedia de Bannos, localidade hoje desconhecida (LIVES...1997: 41, nota 114), mas certamente nomeada por Bráulio com a perspectiva de acentuar a atração que o túmulo do hagiografado exercia em relação aos habitantes do entorno. Nesse propósito, o autor finaliza o relato enfatizando que o milagre poderia ser testemunhado por todos já que era conhecido o local onde a mulher, agora sã, morava.

A última menção deste conjunto diz respeito a um caso de ressurreição de uma menina de quatro anos (c.31). Em busca de cura de grave enfermidade, seus pais a teriam levado ao altar do santo. A criança, que não resiste à viagem, é deixada no local pelos pais. Cheios de fé e esperança, retornam algumas horas depois e se deparam com a menina viva e bem-disposta. A condição infantil da menina é particularmente exposta, já que, embora se trate da maior favorecida, coube aos pais toda a ação na busca pelo milagre. Apesar disso, ou seja, da participação passiva da menina e mesmo se tratando de uma criança, pareceu-nos oportuno que o autor tivesse optado por destacar o mesmo número de casos - dois casos, cada - envolvendo personagens mulheres e homens, ao tratar dos milagres post-mortem. Ainda a propósito do milagre de ressurreição de uma criança, observa-se que sua atenção não se limitou a distribuir as benesses do santo entre diferentes segmentos sociais, mas também a atender a mais de uma faixa etária e, sobretudo, a homens e mulheres de modo equilibrado.

Na sequência do bloco de milagres, antes que a morte do santo seja anunciada, Bráulio, em meio a revelações sobre o convívio de Emiliano com religiosas locais, em provável alusão aos mosteiros dúplices (BANGO TORVISO, 2007: 18), fornece-nos dados sobre suas condições de saúde. Para tal, serve-se mais uma vez do principal antagonista do santo, o demônio. A ele atribui a calúnia que teria circulado sobre a conduta do santo, que, nesta altura, vivia com as virgens sagradas. Além de ressaltar o permanente desejo do inimigo de desqualificar as boas obras e os homens virtuosos, o autor lembra os 80 anos do hagiografado e o quão longe estaria naquela idade dos desejos carnais. ${ }^{16}$ As mulheres, por sua vez, são identificadas como santas (sanctis femininis) ocupadas com os cuidados necessários ao santo hidrópico. São, portanto, 
coadjuvantes passivas em um relato no qual o demônio e Emiliano travam uma batalha: o primeiro propagando a injúria e o segundo caracterizado, no plano moral, como campeão de virtudes, e, no plano físico, como incapacitado dada a avançada idade e estado de enfermidade.

Nesta oportunidade, constata-se a segunda das duas únicas situações em que, sem que haja uma ação milagrosa, a figura feminina é realçada na narrativa. Ainda que em situações bem diferentes, assim como Potâmia foi acionada para testemunhar as virtudes do hagiografado, as religiosas referidas no capítulo 23 são mobilizadas para o trato de questões morais. Neste caso, registra-se a ilibada conduta de Emiliano, apesar do estreito convívio na casa feminina.

Da análise das nove passagens da VSA em que as mulheres são referidas, dentre outros aspectos, podemos ressaltar os seguintes pontos:

Considerando sua participação na narrativa, as várias mulheres presentes na VSA podem ser agrupadas em dois blocos. No maior deles, a relação é mediada pelo milagre. Ou seja, a interação com o santo é direta e promovida a partir de demandas que vão beneficiar as próprias mulheres, são por elas reivindicadas e frequentemente associadas à manifestação de fé. A relação direta ocorre, cabe lembrar, apesar de, especialmente nos casos em que as mulheres procedem da elite ou interagem com ela, haver menção a figuras masculinas. Estes, por sua vez, exercem fundamentalmente a função de fornecer com precisão o lugar social a que cada um pertence. Assim, são aludidos o senador Sicório, cuja criada foi curada; o senador Nepociano que, com sua esposa, Proséria, conseguiu se livrar de um demônio; o curial Máximo, pai de Columba, de quem o santo expulsou outro demônio.

Neste conjunto, observa-se, ainda, a identificação pelo nome da maioria das mulheres. Desse modo, além das integrantes antes mencionadas, são nomeadas Bárbara e Eufrísia. Não recebem a identificação nominal, a criada antes mencionada, a mulher coxa que insiste para estar com o santo na Quaresma e a menina de quatro anos que ressuscitou no oratório emilianense. Em suma, das sete mulheres contempladas com milagres, três são identificadas por uma soma de características que não os respectivos nomes. Tal omissão, entretanto, não as isentam de identidade. Além das suas demandas específicas, a criada é definida por sua situação social, a mulher coxa por sua 
determinação e a menina pela sua condição infantil e, apesar de passiva, beneficiada pelo maior dos milagres descritos pelo hagiógrafo.

No bloco de capítulos dedicados aos milagres há menção a pouco mais de dez personagens masculinos. Mesmo excedendo numericamente às mulheres, assim como elas, são identificados ora por nomes, ora por funções ocupadas ou por suas demandas. Ressalta-se ainda que, apesar de figurarem nos relatos sem a associação a outras pessoas, diferentemente de algumas das beneficiadas antes observadas, de um modo geral, salvo a já referida superioridade numérica, não recebem tratamento especial na relação com o santo.

O segundo bloco compreende as duas referências feitas às mulheres que podem ser identificadas como coadjuvantes na narrativa: Potâmia e as virgens com quem Emiliano habita. Embora sejam aludidas apenas para atestar qualidades do santo, possuem como característica fundamental $o$ fato de pertencerem à instituição eclesiástica. O hagiógrafo desse modo estabelece uma dinâmica de duplo reforço institucional: ao promover essas mulheres por meio do destaque de suas virtudes, confere-lhes a legitimidade necessária para testemunharem acerca da santidade de Emiliano. É evidente que tal santidade está fundamentada em outros aspectos, mas não prescindiu da ratificação feminina.

$\mathrm{Na}$ verdade, o perfil construído para as mulheres ao longo da narrativa é bastante positivo. Além do já sublinhado a respeito, convém demarcar que as dificuldades enfrentadas pelo santo em nenhum dos episódios envolve a ação de mulheres. Os promotores das situações adversas são exclusivamente personagens masculinos. Assim, em alusão ao enquadramento do santo à hierarquia clerical, ${ }^{17}$ é o bispo de Tarazona que lhe confere as ordens sagradas (c. 5) e o adverte, posteriormente, por conduta inadequada (c. 6); são os clérigos que o denunciam por distribuir bens da Igreja (c. 6), são dois homens que roubam seu cavalo (c. 24), é um mendigo que se precipita e toma do santo as vestes que estava prestes a doar (c. 20) e é um homem que duvida da profecia de destruição da Cantábria feita por Emiliano (c. 26).

Por fim, cabe ressaltar que é visível a preocupação do hagiógrafo em atrair um amplo conjunto de interessados na hagiografia e na santidade de Emiliano, para tal dedicou zelo especial a vários atores sociais e cuidou para que ficasse caracterizada a abrangência geográfica da influência. Desse modo, ainda que as mulheres sejam menos 
presentes que os homens, usufruem da atenção do hagiógrafo e recebem o mesmo tratamento que estes do santo. Talvez caiba indicar, inclusive, um olhar para elas ligeiramente favorável, já que são representadas em todas as circunstâncias como beneficiadas e não se identificam com as adversidades experimentadas por Emiliano.

\section{Legenda Beati Petri Gundisalvi ${ }^{18}$}

A legenda dedicada a narrar a vida de Pedro Gonçalves é referenciada por diversos nomes, a saber: Legenda Beati Petri Gundisalvi, Vita S. Petri Cundisalvi, Vita Sancti Petri Gundisalvi O. P. Tudensis ou Legenda B. Petri Confessoris, Ordinis Praedicatorum. Ela está registrada na Bibliotheca hagiographica latina antiquæ et mediæ æatatis sob o número 6711, mas se trata de um texto ainda pouco conhecido e estudado. ${ }^{19}$

A LBPG foi transmitida por dois manuscritos. O mais antigo, que contém a obra de forma incompleta, encontra-se em um códice medieval do Arquivo Capitular Diocesano de Tui, o Ms 1, também conhecido como Passionario de Tui, nos fólios 257r. a 261v. Não existe consenso sobre a datação desta cópia, mas provavelmente foi realizada entre o final do século XIII e início do XIV. O segundo, com o texto integral da legenda, está no Libro Becerro I da Catedral Tudense, datado do século XVI.

O texto copiado no manuscrito medieval foi transcrito por Enrique Flórez e inserido no tomo 23 da España Sagrada, lançado em 1767. Em 2009, foi traduzido para o espanhol e publicado como um dos capítulos de uma obra de Suso Vila sobre a vida e culto a Pedro Gonçalves. Em 2018, foi realizada uma tradução para o português, pelas professoras Andréia C. L. Frazão da Silva e Andrea Reis Ferreira Torres, lançada com recursos da Faperj. Vale sublinhar que essas edições e traduções têm como objetivo divulgar a legenda e não possuem caráter de obra crítica.

Como já anunciado, a LBPG tem como protagonista Pedro Gonçalves, que é mais conhecido atualmente pelo nome Telmo. ${ }^{20}$ É a partir dos dados presentes nessa hagiografia que os estudiosos constroem uma biografia do Santo. Assim, há certo consenso de que ele nasceu em Frómista, localidade do então Reino de Castela, atual Espanha, por volta de 1190. Foi educado na escola da Sé de Palência, onde tornou-se membro do cabido, chegando a ocupar o cargo de Deão. Com cerca de 30 anos, 
ingressou na Ordem dos Pregadores. Como frade, foi capelão junto às tropas castelhanas em expedições lideradas pelo rei Fernando III na Andaluzia e, posteriormente, fixou-se na Galiza, onde atuou como pregador itinerante. Morreu em 1246, na cidade de Tui, sendo sepultado na catedral.

Há evidências de que o culto a Pedro Gonçalves começou a se desenvolver logo após a sua morte. ${ }^{21} \mathrm{Na}$ década de 1250 foi realizado um inquérito para reunir testemunhos sobre os seus milagres, a pedido do bispo de Tui, Gil Peres de Cerveira, que foi enviado ao Capítulo Geral da Ordem dos Pregadores reunido em Toulouse em 1258. Referências às virtudes do Frade e ao inquérito foram incluídas na Vitae Fratrum Ordinis Praedicatorum, composta por volta de 1256, que relata a história inicial dos Dominicanos e a trajetória dos frades que se distinguiram por suas virtudes e milagres (1987, p. 785-786). Em 1269, o testamento de Rodrigo Eans, cônego de Santa Cruz de Coimbra, faz referência à veneração ao santo (VILA, 2009, p. 84). Ainda no século XIII foi composta uma Missa em homenagem a Telmo. ${ }^{22}$

É provável que a LBPG tenha sido redigida nos anos iniciais da década de 1250, associada à elaboração do inquérito dos milagres do santo. Gil Peres de Cerveira, que governou a diocese entre 1250 a 1274 , pode ter ordenado a redação da legenda como uma síntese biográfica sobre Pedro González para acompanhar a relação de milagres ou como ponto de partida para a recolha dos testemunhos. Esse interesse em promover o culto ao frade pode ser explicado por dois motivos principais: até o início do século XIII, não existia um santo patrono vinculado diretamente à trajetória da igreja tudense; era necessário canalizar as atenções dos fiéis para a promoção desse culto, como forma de apaziguar as tensões derivadas dos embates entre o Concello e o Cabido tudenses. ${ }^{23}$

O nome do redator - ou redatores - da LBPG não é conhecido. Alguns estudiosos $^{24}$ propõem que a obra foi composta por um dominicano, o que é bem provável. Contudo, como defendemos que foram a Catedral e o Cabido de Tui que patrocinaram a produção desta obra, é possível que algum clérigo capitular possa ter participado da composição. Também não é conhecido o local de redação da LBPG. Entretanto, dentre todas as regiões citadas no decorrer da narrativa, Tui é a que ganha maior destaque, com especial ênfase à sua Catedral, como local de sepultamento, culto e guarda das relíquias de Pedro Gonçalves. Esse dado permite não só propor que Tui foi o 
local de redação do texto, ${ }^{25}$ mas reafirmar o papel do episcopado como promotor da legenda. ${ }^{26}$

Em seu estado atual, tal como é possível constatar pela análise do manuscrito medieval, ${ }^{27}$ a LBPG está dividida em 15 partes, ${ }^{28}$ provavelmente para ser lida, em etapas, em celebrações vinculadas a São Pedro Gonçalves. Esse dado permite supor que a obra objetivava atingir um grande público: os assistentes às missas na Catedral Tudense, como os clérigos do cabido, os leigos da diocese e os eventuais viajantes pela região.

A grande maioria das leituras contém um relato completo, ou seja, que aborda um tópico específico e/ou descreve um ou mais eventos relacionados. ${ }^{29}$ Passamos a indicar o tema central de cada leitura: a 1 é o prólogo da obra; na 2 são apresentadas as origens familiares de Pedro, a sua primeira educação e ingresso no cabido da catedral palentina; na 3 o foco é a experiência de conversão que culminou no ingresso na vida religiosa mendicante, tema que é desdobrado na leitura seguinte, a 4, na qual é apresentada a Ordem dos Pregadores; na 5 são descritos os estudos realizados após a sua vinculação aos dominicanos, o que é complementado na 6, que caracteriza o religioso como imitador de Santo Domingos de Gusmão; na 7 é sublinhado a sua dedicação à cura pastoral e o convite feito pelo Rei Fernando III para acompanhá-lo nas lutas contra os muçulmanos ao sul da península, o que suscitou a inveja de alguns; as duas leituras seguintes, 8 e 9, relatam tentativas de sedução do Santo por mulheres; nas leituras 10, 11 e 12 são relatados milagres vinculados à alimentação, à reconstrução de pontes e à proteção do povo que o seguia e incluem exortações do Frade; na 13, o pregador anuncia a proximidade de sua morte, que é relatada na 14 e a última leitura, a 15 , apresenta milagres post-mortem, um dos quais de forma incompleta. ${ }^{30}$

Para a elaboração da LBPG, segundo informações presentes no próprio texto, foram utilizados testemunhos orais sobre Pedro González. Também foram incluídas passagens e referências bíblicas e há uma citação explícita ao Homiliarum in Evangelia de Gregório Magno. Como são observadas semelhanças com a Legendae Sancti Dominici, primeira hagiografia dedicada à Domingos de Gusmão, é possível que esta obra tenha inspirado a redação da LBPG.

É perceptível por meio da leitura que a LBPG está composta em ao menos dois estilos literários distintos. As sete primeiras leituras são sintéticas, apresentando eventos 
e caracterizado o protagonista. O tom é sóbrio, repleto de adjetivos que ressaltam as virtudes e boas ações de Pedro e são feitas muitas comparações com figuras bíblicas. Da leitura 8 até o final os textos são mais longos e o santo se relaciona com outros personagens do enredo, como companheiros de pregação e viagem, o rei Fernando III, mulheres e clérigos, que são descritos e agem na narrativa. A trama também fica mais complexa, pois são relatados milagres, intrigas, tentativas de sedução, etc. A própria forma de tratamento do protagonista também muda, que passa a ser referenciado como frater Petre. Tais características textuais permitem supor que o material foi elaborado em etapas e sofreu a ação de ao menos dois autores.

Por fim, há que salientar que a trajetória de Pedro Gonçalves na LBPG é contada por um narrador onisciente, em terceira pessoa, que conhece todos os eventos, pensamentos, sentimentos e intenções dos personagens. Salvo no prólogo e em poucas passagens pontuais, nos quais apresenta opiniões, não faz intromissões ou se dirige ao público. Utilizando diversos recursos, como descrição, diálogos, comparações, citações de textos, a legenda apresenta um santo que se distingue, sobretudo, por seu diligente compromisso pastoral.

A seguir, vamos apresentar e discutir a presença de mulheres na LBPG, considerando os elementos acima expostos e com foco no sentido impresso na narrativa em sua forma atual.

\section{As mulheres na Legenda Beati Petri Gundisalvi}

Há uma pequena presença das mulheres na LBPG. Primeiramente, destaca-se que, no decorrer do texto, quando o narrador ou algum personagem se refere a grupos nos quais há mulheres, sempre utiliza expressões abrangentes, ao invés de precisá-las como a parte de um todo. Desta forma, no decorrer da LBPG, são usados os termos "santos/sanctis" para indicar as diversas categorias de venerados, sem ressaltar as virgens, os confessores, mártires (Leitura 1); "pais/ parentibus", ao invés da expressão "mãe e pai" para mencionar os genitores de Pedro (Leitura 2); "homens/ homines; hominum" (Leituras 1, 3, 11, 13) ou somente "almas/ animarum; animi" (Leituras 6, 7, 8) para denominar toda a humanidade, ou ainda, para se referir aos que habitavam em uma casa, cita os "senhores de casa, seus filhos e todos os criados/domus dominos 
necnon \& eorum filios ac domésticos" (Leitura 6). Esse recurso não era uma regra absoluta no período. Por exemplo, em diversas passagens das obras de Gonzalo de Berceo, poeta castelhano contemporâneo à redação da LBPG, são utilizadas expressões como "varões e mulheres" e "santos e santas", dando visibilidade à presença feminina em um conjunto de pessoas. ${ }^{31}$

Outro aspecto a destacar é a inexistência de referências a mulheres mencionadas nas escrituras e/ou veneradas como santas. Como assinalamos anteriormente, no decorrer da legenda, são feitas alusões a personagens bíblicos e/ou santos para realçar as virtudes de Pedro. Assim, o protagonista era estudioso como Salomão (Leitura 2); arrependeu-se como o apóstolo Pedro (Leitura 4); era guiado pelo exemplo de Santo Domingos de Gusmão (Leitura 6); era repleto de virtudes como Judas Macabeu (Leitura 7), para citar alguns exemplos. Ou seja, todos os inseridos no relato são homens e nenhuma mulher, ainda que notável por sua santidade, como Maria, mãe de Cristo, é indicada na LBPG como um modelo para o frade. Pode-se argumentar que essa associação unicamente com homens exemplares deriva do fato de Pedro ser um homem, o que é plausível. Contudo, as mulheres santas não figuram na hagiografia nem como objeto de devoção do santo, como ocorre, por exemplo, na Legenda Maior de Boaventura, que sublinha em diversas passagens que Francisco de Assis possuía especial veneração por Maria. ${ }^{32}$

As mulheres não são particularizadas como parte do todo ou citadas como exemplares ou, se santas, veneradas pelo protagonista na LBPG. Elas, porém, figuram como personagens ativas na trama. Mas estão em minoria, só presentes em 4 do conjunto de 15 leituras: na 8,9,10 e 15. Passamos a discutir as passagens nas quais as mulheres estão presentes.

A Leitura 8 narra um milagre ocorrido quando, na sequência da narrativa, Pedro já era frade pregador e alcançara fama por sua atividade pastoral e virtudes. Como é relatado na Leitura 7, a reputação do religioso havia chegado até Fernando III, que o convidou para acompanhá-lo nas campanhas contra os muçulmanos estabelecidos nas fronteiras do reino. $\mathrm{O}$ evento apresentado na Leitura 8 ocorre quando Pedro já está junto ao rei na cidade Hispalensis, atual Sevilha. O local específico no qual o episódio sucede é uma espécie de hospedaria, na qual se encontravam os personagens que têm atuação na narrativa: o irmão Pedro, um companheiro, alguns soldados e uma mulher. 
Pedro é um "homem de Deus", que demonstra compaixão, é cauteloso e está sempre disponível para ouvir confissões. O seu companheiro não é qualificado. Os soldados são divididos em dois grandes grupos: os que reconheciam a santidade do dominicano, e os que a negavam. Esses últimos são identificados como malévolos (malevolis) e invejosos (hasta invidiae, agitatis \& motis praecipue). A mulher é caracterizada como pecadora, "vaso de maldade" e "cheia de toda falsidade diabólica". ${ }^{33}$ Ela se ofereceu para ser cúmplice dos que não acreditavam na santidade de Pedro, a fim de seduzi-lo em troca de dinheiro. ${ }^{34}$ Não é explicitado, mas, pelo contexto narrativo, é possível concluir que fosse uma prostituta que acompanhava as tropas ou que exercia a sua atividade junto ao local de hospedagem. ${ }^{35} \mathrm{Na}$ leitura, ela ganha voz e suas falas aparecem em discurso direto.

A mulher figura inicialmente se relacionando com os soldados que não criam na santidade do Frade e julgavam que ele repreendia, excessivamente, a luxúria de todos, inclusive a do rei, exortando-os à abstinência e à oração. Como assinalado, ela se ofereceu para seduzir o santo. A sugestão foi aceita e os "malévolos" prometeram pagála por essa ação. Nesse ponto, um questionamento se faz necessário: o narrador diz que a mulher foi até Pedro motivada pelo pedido dos soldados e pelo dinheiro que receberia. $^{36}$ Mas a ideia de tentar o religioso em troca de dinheiro não partiu, inicialmente, da própria mulher? Por que incluir na narrativa uma espécie de atenuante para os seus atos, tornando os homens corresponsáveis da sedução?

A mulher, então, procura o santo. Apesar de rechaçada pelo companheiro de Pedro, ela conseguiu chegar até ele, alegando que precisava vê-lo, senão morreria. A narrativa descreve esse encontro, com diversos detalhes. ${ }^{37}$ Por exemplo, registra como o dominicano, apesar de compadecido, suspeitou da mulher, e descreve os gestos e argumentos usados pela pecadora - ajoelhar-se, chorar copiosamente e pedir para confessar - para convencer o frade. Provavelmente para reforçar a pureza do santo, o relato informa que ele sugeriu que a mulher esperasse até amanhecer, mas ela insistiu sobre a importância de confessar imediatamente, pois acreditava que morreria ainda durante a noite. Assim, o frade, concordou em ouvi-la. A mulher, então, anunciou, em discurso direto, que o amava e iria morrer antes da meia noite, caso não ficasse com ele.

Pedro tentou dissuadi-la, mas a mulher não recuou. O texto então registra que percebendo a maldade da mulher, o santo mudou de estratégia, informando que iria 
preparar um leito. ${ }^{38}$ Ocorre então o milagre: Pedro colocou sua capa sobre brasas ardentes e deitou sobre ela, convidando a mulher a acompanhá-lo, fala que também é registrada em discurso direto. A mulher e os soldados que a contrataram - que espiavam tudo pelas frestas de uma porta - reconheceram o milagre e se arrependeram. A leitura finaliza ressaltando que a pecadora mudou de vida, passando a servir a Deus.

A Leitura 9 inicia destacando que irá relatar um evento semelhante ao anterior. A seguir, localiza o fato a ser narrado tanto espacialmente - Diocese de Lugo -, quanto temporalmente - após a tomada de Sevilha. Informa, ainda, que Pedro havia retornado com o rei para Castela e fora designado para o Convento Dominicano de Santiago de Compostela. Após situar o episódio, são feitas duas observações iniciais, com a função de nortear a compreensão do texto. A primeira, que o dominicano, quando pregava na diocese lucense, ficava hospedado na casa de um cura. A segunda, relacionada à aparência e ao temperamento do frade: "embora fosse de pequena estatura, sem dúvida era agradável quanto ao aspecto, suave nas palavras, de rosto alegre, de total honestidade interna e externa, e foi impelido pelos afetos de todos os que o admiravam". 39

Após apresentar essas informações, a narrativa destaca que durante uma hospedagem em Lugo, o santo foi mais afável com uma criada da casa, com "intentione sincera", objetivando levá-la à penitência. Ela é qualificada como pecadora, má e cheia de desejo pelo frade, pois tomou as suas santas intenções em outro sentido. Assim, tentou atrair o religioso com palavras e gestos não puros (verbis ac gestibus impudicis) e durante a noite chegou a entrar no quarto onde Pedro se encontrava, pedindo para dormir com ele. Em resposta, o dominicano procedeu da mesma forma que na leitura anterior: colocou sua capa sobre o fogo, deitou-se e convidou a mulher para fazer o mesmo.

O relato salienta o espanto da mulher, que chamou o cura e os outros criados da casa para presenciar o milagre. E aí é feita uma nova observação pelo narrador: que os que foram cúmplices do evento confessaram e reconheceram a santidade de Pedro. Mais uma vez a narrativa parece contradizer-se. Inicialmente, a sedução da mulher é apresentada como o resultado de uma interpretação errônea da afabilidade de frade, movida por sua natureza má. Mas essa última observação indica que a investida da criada em relação ao Santo foi fruto de um plano daqueles que queriam testar a sua 
santidade. A leitura finaliza com uma reflexão do narrador, que enaltece o amor ardente de Pedro pelo Criador e o próprio milagre, comparando-o com o episódio bíblico no qual três jovens são colocados no forno sem receber dano. ${ }^{40}$

A Leitura 10 relata outro milagre no qual figura uma mulher, mas possui características diferentes. O evento também ocorreu na Diocese de Lugo, onde Pedro e um companheiro, segundo a obra, permaneceram para pregar. Esse episódio envolve quatro personagens - o Frade e um companheiro, um clérigo e a sua governanta - que não recebem adjetivações. Vale destacar que, como na Leitura 8 , as falas da mulher são apresentadas, assim como algumas do santo, em discurso direto.

O fato ocorre quando Pedro e seu companheiro, cansados e com sede, chegam a uma igreja e encontram a governanta de um clérigo, a quem pedem algo para beber. Ela afirma que na casa só havia um pouco de vinho, mas o cura havia ordenado que fosse guardado para ele, acrescentando que se desse para eles, estaria em perigo. $O$ hagiografado contesta a mulher, em discurso direto, sublinhando o poder e a proteção de Deus. Com as palavras do religioso, a mulher se enche de confiança ${ }^{41}$ e entrega o vinho aos frades, que bebem e partem.

Logo depois chega o clérigo, que encontra um vinho muito superior e não entende o que aconteceu. Ele questiona a governanta, que, segundo a narrativa, já ia embora por medo do clérigo, ou seja, havia perdido a confiança obtida na conversa com Pedro. Ela contou o que sucedeu, dando-se conta, então, do milagre. Assim, começou a gritar e a exortar o seu patrão. ${ }^{42} \mathrm{O}$ clérigo ficou assustado e procurou pelo frade, relatando o milagre e chamando-o a comer em sua casa. A leitura termina com a resposta do santo, em discurso direto, no qual rejeita o convite e tranquiliza o cura, destacando que Deus pode ajudar, mesmo quando a necessidade é grande.

A última leitura na qual há uma mulher entre as personagens, é a 15, que, como já assinalado, foi transmitida de forma incompleta. Nela são narrados dois milagres de Pedro após a morte, ocorridos em Tui, mas só vamos abordar o segundo, pois é nele que a mulher atua como personagem. Vale destacar que apesar do milagre ter ocorrido após a morte do santo, a primeira parte do relato referencia uma promessa, apresentada em discurso direto, feita quando o frade ainda vivia. Ou seja, o episódio se situa temporalmente em dois momentos. 
A mulher que figura nesse relato é muito diferente das anteriormente aludidas. Segundo a LBPG, ela era nobre, devota de Pedro e o hospedara frequentemente. O ponto central é o pedido feito por essa mulher ao santo, quando ele ainda vivia, de que lhe deixasse uma recordação. Segundo a narrativa, o frade teria lhe dito: "Senhora, vossa justa petição, vivo ou morto, tentarei satisfazê-la". ${ }^{43}$ Ao saber da morte do santo, a nobre ficou desconsolada, pois não recebera o que desejara. Mas, no desenrolar da trama, Pedro apareceu na mente da mulher, ordenou que ela fosse até o seu sepulcro e prometeu que ali lhe daria o que almejava. Como o relato não está completo, só nos resta supor que algo maravilhoso ocorreu e a senhora obteve a sua relíquia.

Após a análise narrativa dos trechos da LBPG no qual há mulheres, podemos traçar algumas considerações. Em primeiro lugar, as mulheres só figuram de forma explícita na obra nos relatos nos quais são personagens ativas da trama. Ainda que em diversos pontos é possível supor a presença/menção a mulheres, a linguagem empregada no texto opta por usar sempre o masculino no sentido geral, sem salientar que o todo era formado por homens e mulheres. Também não são mencionadas mulheres, mesmo que santas, como exemplares ou porque veneradas pelo protagonista.

As personagens mulheres, comparadas aos homens, são minoria. Nenhuma das quatro mulheres é denominada ou qualquer outro detalhe é incluído, como local de origem, idade, estado matrimonial, etc. Só somos informadas por seu papel social: duas são criadas de clérigos, uma é nobre e outra, como é possível concluir pela narrativa, é uma prostituta. Elas podem ser divididas em dois grandes grupos: aquelas que tentam e as que ajudam ao Santo.

O hagiografado é muito amável com as mulheres em toda a obra, seja com as que buscaram tentá-lo, mesmo quando ele desconfia de suas intenções, ou aquelas que o acolheram, dando-o o que beber ou hospedando-o em sua casa. A narrativa, contudo, busca realçar a pureza dessa afabilidade do Santo para com as mulheres, salientando que seu objetivo era unicamente a pastoral. Desta forma, nos três relatos que conhecemos o final, as mulheres vivem experiências de fé: se arrependem, mudam de viva, fortalecem sua confiança em Deus.

Vale sublinhar que, das quatro mulheres, três têm as suas falas registradas em discurso direto. ${ }^{44}$ Esse dado é digno de nota, pois além do próprio Pedro, só mais um personagem tem um curto pronunciamento registrado dessa forma. ${ }^{45}$ É como se o relato 
buscasse realçar o papel desse grupo de personagens. Mas com qual objetivo? Nas quatro aparições as mulheres têm papel ativo nos episódios, mas em todos eles o santo é, ao fim e ao cabo, o principal beneficiado. Em dois episódios ele é tentado em sua castidade; ele resiste, demonstrando a sua virtude, e, por extensão, protegendo a sua fama. Nos demais, o dominicano atua para compensar algo que foi dado a ele - a bebida e a hospedagem. Assim, ainda que em minoria no conjunto da obra, as mulheres têm uma função chave: reafirmar a santidade de Pedro.

Contudo a performance de duas dessas mulheres parece ambígua. No primeiro milagre no qual o frade é tentado, na sequência narrativa, a mulher, primeiro, oferece-se para seduzi-lo. No segundo, é realçado que a criada interpreta erroneamente o tratamento gentil de Pedro. Ou seja, as seduções são explicadas no relato, primeiramente, como fruto da maldade dessas mulheres. Como o demônio não participa da trama como adversário, as tentadoras parecem ocupar esse papel de antagonista. Porém, no desenrolar do enredo, o hagiógrafo registra que elas agiram com o apoio de outros homens. Tal encaminhamento diminuí a autonomia de seus atos e o seu protagonismo, ainda que negativo, nos eventos, sugerindo que, mesmo para praticar um pecado, a mulher precisa ser apoiada pelos homens. Ou seja, ainda que más, as mulheres carecem da ajuda dos homens.

Essa visão negativa das mulheres pode ser percebida também nos relatos nos quais as mulheres agem a favor do santo. Na multiplicação do vinho, como já assinalado, a governanta, inspirada por Deus por meio da fala do frade, ganha coragem e dá a pouca bebida disponível para os pregadores. Mas essa confiança se desfaz pouco depois, pois ela teme a repreensão do seu patrão, chegando a tentar fugir de sua presença. Ela só é empoderada ao constatar o milagre operado por intermédio do santo, ao ponto de exortar o cura, aos gritos, qualificando-o como pecador. A senhora nobre, mesmo ciente da promessa feita pelo hagiografado, fica muito triste ao saber de sua morte, porque não recebera a lembrança desejada, demonstrando certo descrédito para com as palavras de Pedro. 


\section{As mulheres na VSA e na LBPG em perspectiva comparativa}

Como já assinalado, as duas obras analisadas são hagiografias, mais precisamente, vida de santos, pois relatam trajetórias desde o nascimento até a morte, com destaque para as virtudes e os atos maravilhosos em vida e os milagres operados post-mortem. Ambas foram compostas na Península Ibérica, poucos anos após a morte dos santos, mas em contextos bem distintos.

A VSA foi elaborada quando o cristianismo niceno ainda se organizava institucionalmente na região. Embora as estruturas eclesiásticas estivessem presentes e a conversão de Recaredo, há aproximadamente meio século, tivesse favorecido a expansão da fé, ainda havia muito a realizar, especialmente em áreas rurais. Nesse processo, a ação episcopal assumiu enorme destaque, o que pode ser evidenciado, por exemplo, no volume de textos produzidos naquela conjuntura. A LBPG, dentre outros aspectos, quando o cristianismo já estava consolidado e organizado hierarquicamente, articulando instâncias locais - dioceses e arcebispados -, com as de pretensão universal - o papado -, e as diversas ordens religiosas, estabelecidas em diversas localidades, seguindo formas de vida específicas, mas vinculando-se às demais instâncias.

O autor da VSA é conhecido. Trata-se do bispo Bráulio, notável por sua atuação como integrante do episcopado, influência política e por sua produção literária. A LBPG não possui autoria conhecida, mas a sua elaboração ocorreu em ambiente clerical, com grande probabilidade por patrocínio da catedral e o cabido de Tui. Os hagiógrafos estavam imersos nas particularidades conjunturais em que produziram suas obras, e, ao compô-las, consideraram não só as memórias existentes sobre os santos protagonistas em disputa, os problemas vividos pela igreja local, os conflitos de poder, mas também as tradições hagiográficas, as doutrinas eclesiásticas, dentre outros elementos.

As narrativas presentes na VSA e na LBPG, ainda que sejam vidas de santos e partilhem de topoi do gênero, possuem diferenças quanto à extensão, estilo literário e conteúdo. A VSA possui 31 capítulos, a LBPG, 15 leituras. A VSA é repleta de registros milagrosos, com destaque para curas e manifestações demoníacas. Ainda que o perfil eremítico de Emiliano seja sutilmente criticado, com seu enquadramento institucional, o destaque da narrativa recaí sobre a grande quantidade de milagres que realiza. Destes, os favorecidos são principalmente os homens e mulheres que lhe procuram, cabendo ao 
santo apenas o benefício indireto de tal atuação, ou seja, o reforço de sua santidade a cada evento. A LBPG ressalta, sobretudo, o ingresso de Pedro na Ordem dos Pregadores e sua atividade pastoral como frade, mencionando sua ação na construção de pontes e alguns poucos milagres, oito ao todo, ${ }^{46}$ dentre os quais a maioria beneficia o próprio santo, pois reafirmam a sua santidade e/ou recompensam aqueles que o ajudaram.

Quanto às mulheres, ainda que sejam representadas na VSA e na LBPG de modos distintos, assumem lugar de destaque em ambas narrativas. Assim, na VSA, ao não se diferenciarem consideravelmente dos homens no tratamento que lhes é conferido pelo santo, reforçam a santidade de Emiliano junto às próprias mulheres. Ao figurarem como beneficiadas que integram diferentes grupos sociais, corroboram a influência do santo junto às populações simples e à elite. Na LBPG, mesmo que numericamente pouco expressivas, destacam-se, especialmente, porque são as principais antagonistas do santo e colocam em questão as suas virtudes.

Cabe sublinhar que, na VSA, este papel negativo está reservado a alguns homens, que desafiam ou incomodam o santo, e especialmente ao demônio. Ele é, portanto, o maior responsável pelos desafios a serem superados pelo hagiografado. Ainda que na LBPG a maldade não seja um privilégio das mulheres, já que alguns homens são igualmente caracterizados como perversos, coube-lhes majoritariamente tal atributo. Contudo, há particularidades nessa qualificação. Se por um lado as mulheres são personagens ativas na narrativa, com direito, inclusive, à voz, por outro, o relato busca realçar o quanto elas são dependentes dos homens, porque são, sobretudo, inconstantes em seus sentimentos, mesmo quando agem de forma positiva, auxiliando o santo.

Na VSA, as mulheres são nomeadas e/ou identificadas por suas demandas, status social e procedência geográfica. Estabelece-se, desse modo, familiaridade em uma comunidade que o autor deseja caracterizar como ampla. Em outras palavras, os benefícios concedidos seriam tão largamente conhecidos que os nomes e/ou demais detalhes sobre as favorecidas poderiam ser facilmente elencados. E mais, busca-se qualificar a influência do santo como algo exercido por um raio que compreenderia não apenas sua localidade, mas atrairia mulheres de áreas do entorno.

Na LBPG, não há a preocupação em particularizar as mulheres por seu nome ou estado matrimonial. Elas só são distinguidas por suas funções, o que serve para imprimir o sentido de que Pedro se relacionava com todos os segmentos sociais. Ele é 
retratado agindo com gentileza com todas as personagens femininas, mesmo com as que querem tentá-lo, mas o faz sempre em nome da sua missão pastoral, que é o principal traço de sua santidade. Os contatos estabelecidos pelo frade com as mulheres nos episódios narrados não respondem a demandas específicas delas e, como já pontuado, ao final, reforçam a sua santidade. Sua ação em prol delas é de caráter espiritual, pois objetiva a aproximação com o divino.

Como explicar as diferenças entre as hagiografias?

Em meio ao processo de fortalecimento da instituição eclesiástica nos séculos VI e VII, o texto hagiográfico potencialmente se constituía como instrumento de cristianização. O registro das memórias do santo, campeão de virtudes, exemplo de vida e evidência do poder divino, contribuía concomitantemente àquele processo e ao reforço do prestígio local de Bráulio e sua família, no caso da VSA. Embora à instituição interessasse o enquadramento de figuras com o perfil eremítico de Emiliano, sua influência junto às populações também poderia ser aproveitada por meio do controle do seu culto. Assim, ainda que na VSA existam elementos que realcem o reconhecimento da autoridade eclesiástica, como o episódio envolvendo sua sagração pelo bispo de Tarazona, o hagiografado é caracterizado sobretudo como um eremita.

Nesta condição, deseja permanentemente viver em isolamento e só entra em contato com as mulheres quando é procurado. Ou seja, excetuando sua proximidade com as virgens devido às necessidades oriundas de sua avançada idade e doença, não há registro de que compartilhasse do convívio feminino. Desse modo, as mulheres atestam a santidade do Emiliano porque recebem graças por intermédio dele. Elas não o desafiam, ao contrário, buscam suas benesses no enfrentamento de doenças, possessões, de demais adversidades.

Considerando que a LBPG foi elaborada por eclesiásticos em um ambiente clerical, da catedral e do cabido de Tui, compreende-se que todos os modelos de santidade e autoridades invocadas sejam homens. Nesse mesmo sentido devemos interpretar as mulheres com atuação ativa na obra, que servem ao propósito de atestar a santidade do hagiografado, mas são retratadas como inconstantes.

A LBPG foi composta quando a ordem dos pregadores se expandia e se consolidava pelo Ocidente, o que, certamente, ainda levantava suspeitas devido, 
sobretudo, às práticas da itinerância e pobreza. Desta forma, ao realçar a trajetória de um santo pregador, tomado como patrono particular da catedral de Tui, era necessário retratá-lo em atividade compatível com a esperada dos integrantes da nascente ordem mendicante. Essa atuação, inevitavelmente, exigia o convívio em ambientes como hospedarias, casas particulares, estradas e templos, nos quais o contato com as mulheres não poderia ser restrito. Esses contatos são associados, no âmbito narrativo, à sua atividade pastoral e, sobretudo, ao seu zelo pela alma dos pecadores, seu principal traço de santidade.

\section{BIBLIOGRAFIA}

BRAULIO DE ZARAGOZA. Epístolas. Edición Ruth Miguel Franco. Madrid: Akal, 2015.

BRAULIO OF SARAGOSSA. The life of St Aemilian the confessor, called the hooded. Lives of the visigothic fathers. Translated and edited by A.T. Fear. Liverpool: Liverpool University Press, 1977, p. 15-43.

BRAULIONIS. Sancti Caesaraugustani episcopi. Vita S. Emiliani. Edición crítica por Luis Vázquez de Parga. Madrid: Instituto Jeronimo Zurita, 1943.

DÍAZ Y DÍAZ, M. C. Sobre la compilación hagiográfica de Valerio del Bierzo. Hispania Sacra, v. 4, n. 7, p. 3-25, enero/jun., 1951.

FERNÁNDEZ CONDE, Francisco Javier. La religiosidad medieval en España: Plena Edad Media, ss. XI-XII. Oviedo: Universidad de Oviedo, 2000.

FLÓREZ, Enrique. España Sagrada. Madrid: Antonio Marin, 1767. 56t., T. 23.

FLUDERNIK, Monika. An Introduction to Narratology. London and New York: Routledge, 2009.

GALMÉS, Lorenzo. El bienaventurado Fray Pedro González O.P. San Telmo: Estudio histórico-hagiográfico de su vida y su culto. Salamanca-Tui: Editorial San Esteban - Cofradía de San Telmo, 1991.

GARCÍA DE LA BORBOLLA, Angeles. El universo de lo maravilloso en la Hagiografía Castellana. Boletín de la Real Academia de las Buenas Letras de Barcelona, Barcelona, v. 47, n. 1, p. 335-353, 1999-2000.

La materialidad externa de los santos: sepulcros, reliquias y peregrinaciones en la hagiografía castellano-leonesa (siglo XIII). Medievalismo: Boletín de la Sociedad Española de Estudios Medievales, Madrid, v. 11, n. 1, p. 9-32, 2001.

La función del santo a partir de los relatos hagiográficos. In: ESPAÑOL, Francesca; FITÉ, Francesc (Eds.). Hagiografía peninsular en els segles medievals. Lleida: Universidad de Lleida, 2008. p. 217-233. 
Algunas consideraciones sobre la predicación medieval a partir de la hagiografía mendicante. Erebea: Revista de Humanidades y Ciencias Sociales, Huelva, v. 1, n. 1, p. 57-81, 2011.

GERARDUS DE FRACHETO. Vitae Fratrum Ordinis Praedicatorum. In: GELABERT Fr., Miguel; MILAGRO Fr., José Maria (Ed.). Santo Domingo de Guzman visto por sus contemporâneos. Madrid: BAC, 1967. p. 516-819.

GRANGE, Huw. Saints and Monsters in Medieval French and Occitan Literature: Sublime and Abject Bodies. Cambridge: Legenda, 2017.

GRØNLIE, Siân E. The Saint and the Saga Hero: Hagiography and Early Icelandic Literature. Woodbridge UK: D.S. Brewer, 2017.

JOÃO DE SANTARÉM (Biclarense). Crónica. Ed. Crítica e introdução de Carmen Cardelle de Hartmann. Lisboa: Colibri, 2002.

LA LÉGENDE DE SAINTE POTAMIA (VIe siècle). Ed. Marius Férotin. Analecta Bollandiana, Bruxellis, 21, p. 40-42, 1902.

LA VIDA DE SAN FRUCTUOSO DE BRAGA. Estudio y edición crítica de Manuel C Díaz y Díaz. Braga: Imprensa do Diário do Minho, 1974.

LOMAS SALMONTE, Francisco Javier. Análisis y funcionalidad de la "Vita Aemiliani" (BHL 100). Studia Historica. Historia antigua, n. 16, p. 247-266, 1998.

LIVES OF THE VISIGOTHIC FATHERS. Translated and edited by A.T. FEAR. Liverpool University Press: Liverpool, 1977.

LYNCH, C. H. y GALINDO, P. San Braulio, obispo de Zaragoza. Sua vida y sus obras. Madrid: Instituto Enrique Florez. CSIC, 1950.

MASKARINEC, Maya. City of Saints: Rebuilding Rome in the Early Middle Ages. Philadelphia. PA: University of Pennsylvania Press, 2018.

ORTIZ DE GUINEA, Lina Fernández. Participación episcopal en la articulación de la vida política hispano-visigoda. Studia Historica. Historia Antigua, Salamanca, n.12, p. 159-168, 1994.

PÉREZ-EMBID WAMBA, J. Hagiología y sociedad en la España Medieval: Castilla y León (Siglos XI-XIII). Huelva: Universidad de Huelva, 2002.

- Sobre el trasfondo social de la predicación mendicante en Castilla y León (siglo XIII). Erebea: Revista de Humanidades y Ciencias Sociales, n. 1, p. 103-136, 2011.

PETERSEN, Nils et all. Symbolic Identity and the Cultural Memory of Saints. Newcastle upon Tyne, UK: Cambridge Scholars Publishing, 2018.

SÁNCHEZ-ROMATE, M. J. G. Mujeres cotidianas en Berceo. Medievalia, Mexico, n. 10, p. 1-13, 1992.

SANTIAGO CASTELLANOS. Aristocracias y dependientes en el alto ebro (Siglos VVIII). Studia Historica. Historia Medieval, Salamanca, v. 14, p. 29-46, 1996.

. La hagiografia visigoda. Domínio social y proyección cultural. Logroño: Fundación San Millán de la Cogolla, 2004.

_. Poder social, aristocracias y hombre santo en la Hispania Visigoda. Logroño: Universidad de la Rioja, 1998. 
SILVA, Andréia Cristina Lopes Frazão da. A legenda Beati Petri Gundisalvi: reflexões sobre a relação entre a Ordem dos Pregadores, a Diocese de Tui e a escrita hagiográfica. História [online]. 2017, vol.36, e8. Epub June 22, 2017. Disponível em: http://www.scielo.br/pdf/his/v36/0101-9074-his-36-e8.pdf

. Una diócesis de frontera en busca de un santo patrono: la promoción del culto a Pedro González en Tui en el siglo XIII. Madrygal. Revista de Estudios Gallegos. Madrid, v.20, p.211 - 220, 2017.

SILVA, Andréia Cristina Lopes Frazão da; TORRES, Andrea Reis Ferreira (Eds.) Legenda Beati Petri Gundisalvi. Rio de Janeiro: Programa de Estudos Medievais, 2018.

. (Eds.) Milagres do servo de Deus depois de sua morte e Solenidade ao Beato Pedro Gonçalves. Rio de Janeiro: Programa de Estudos Medievais, 2019.

SILVA, Leila Rodrigues. Vidas de Santos e Relações de Poder na Península Ibérica (séculos VI - VII). In: OLIVEIRA, T. (Org.). Antigüidade e Medievo. Olhares Histórico-Filosóficos da Educação. Maringá: EDUEM, 2008, p. 293-309.

SMITH, Rachel J. D. Excessive Saints: Gender, Narrative, and Theological Invention in Thomas of Cantimpré's Mystical Hagiographies. Gender, Theory, and Religion Series. Columbia University Press, 2019.

SOCII BOLLANDIANI. Bibliotheca hagiographica latina antiqua et mediae atatis. Bruxellis: Société des Bollandistes, 1898-1901, 3t., T. 1 e 2.

VITA S. AEMILIANI CONFESSORIS. Patrologia latina. Paris: Migne, 1850. V. 80, col. 699-714.

VALCÁRCEL, V. La Vita Emiliani de Braulio de Zaragoza: el autor, la cronología y los motivos para su redacción. Helmantica, 147, 375-407, 1997.

VEYNE, Paul. O Inventário das Diferenças: História e Sociologia. São Paulo: Brasiliense, 1983.

VILA-BOTANES, Suso. Corpo Santo San Telmo. Pontevedra: Cofradía de San Telmo de Tui, 2009b.

\footnotetext{
${ }^{1}$ Dentre outros, a título de exemplificação, remetemos aos trabalhos incluídos na bibliografia final, além da produção dos docentes e discentes do Programa de Estudos Medievais da UFRJ (www.pem.historia.ufrj.br).

${ }^{2}$ São denominados "Vidas de Santos" os relatos que narram o percurso de uma figura considerada digna de veneração e seus feitos maravilhosos em vida e após a morte.

${ }^{3}$ Indicamos alguns títulos recentes que ilustram essa diversidade de pesquisas: Excessive Saints: Gender, Narrative, and Theological Invention in Thomas of Cantimpré's Mystical Hagiographies. Gender, Theory, 2019; City of Saints: Rebuilding Rome in the Early Middle Ages, 2018; Symbolic Identity and the Cultural Memory of Saints, 2018; Saints and Monsters in Medieval French and Occitan Literature: Sublime and Abject Bodies, 2017; The Saint and the Saga Hero: Hagiography and Early Icelandic Literature, 2017. A referência completa dessas publicações se encontra na bibliografia final.

${ }^{4}$ Estamos cientes das discussões teóricas relacionadas às construções, no decorrer da história, dos saberes sobre a diferença sexual. Para o desenvolvimento das reflexões aqui apresentadas não realizamos uma conceituação prévia de mulher, adotando como ponto de partida a identificação presente nas hagiografias analisadas.
} 
${ }^{5}$ Considerando que a apresentação de uma comparação das mulheres face aos homens também referenciados nas legendas analisadas ampliaria as nossas conclusões, planejamos publicar estas reflexões em outra ocasião.

${ }^{6}$ Referimo-nos especificamente às reflexões presentes na obra $O$ inventário das diferenças: história e sociologia (1983).

7 "A narrative (Fr. récit; Ger. Erzählung) is a representation of a possible world in a linguistic and/or visual medium, at whose centre there are one or several protagonists of an anthropomorphic nature who are existentially anchored in a temporal and spatial sense and who (mostly) perform goal-directed actions (action and plot structure)" (FLUDERNIK, 2009: 6).

${ }^{8}$ Projeto contemplado no Edital FAPERJ 08/2015 - Programa Apoio a Projetos de Pesquisa na Área de Humanidades - 2015, a ser desenvolvido no período de 2018 a 2021.

${ }^{9}$ Esse projeto foi financiado por meio da Bolsa Cientista do Nosso Estado, Edital FAPERJ 05/2015, e desenvolvido no período de 2015 a 2019.

${ }^{10}$ Ao longo do texto, adotamos a abreviatura VSA, ao nos referirmos à Vita Sancti Aemiliani e "c." aos capítulos/parágrafos temáticos da obra. Registramos, ainda, que para as eventuais referências ao texto latino, utilizaremos a edição da Patrologia Latina.

${ }^{11}$ Essa tese foi amplamente desenvolvida por Santiago Castelhanos. Cf. SANTIAGO CASTELLANOS, 1996: SANTIAGO CASTELLANOS, 1998 e SANTIAGO CASTELLANOS, 2004.

12 "Potamiae cujus nobiliem ortum nobilier vitae nobiliiavit cursus". VSA, 1850: col.704.

13 “... beatae memoriae religiosissimae Potamiae”. VSA, 1850: col.704.

${ }^{14}$ A localidade, que dista aproximadamente $150 \mathrm{Km}$ do atual mosteiro de San Millán, é referenciada em outros textos da época, com destaque para a alusão na Crônica de Juan de Bíclaro que descreve a ação de Leovigildo na Cantábria, com a ocupação de Amaia. Cf. JOÃO DE SANTARÉM, 2002: c. 32, 131.

15 “....ut corpus effectum uxori vinculum, unus ab uno crederetur incoli spiritu...”. VSA, 1850: col.708.

16 "Sed jam, ut praenrisi, ita a nefandis incitamentis erat extraneus, ut ae vestigium quidem inhonesti motus in illa aetate fuerit expertus". VSA, 1850: col. 711.

${ }^{17}$ A temática do reconhecimento da autoridade eclesiástica e o eremitismo de Emiliano, já foi amplamente abordada em outros publicações das autoras. Cf., por exemplo, SILVA, 2008: 293-309.

${ }^{18}$ Ao longo do texto adotamos a sigla LBPG para identificar essa obra.

${ }^{19}$ A LBPG foi utilizada pelos biógrafos e estudiosos do culto a Pedro Gonçalves, como Galmés (1991) e Suso Vila (2009), e por aqueles que têm como escopo o estudo da hagiografia ibérica medieval e o impacto dos mendicantes nos ideais de santidade, como Fernández Conde (2000) e García de la Borbolla (1999-2000, 2001, 2008, 2011). Salvo os trabalhos realizados por Silva $(2017,2018,2019)$, não foram localizados textos que analisem, de forma específica, a LBPG.

${ }^{20}$ O nome Telmo advém, segundo Galmés (1991), da associação com o Santo Erasmo, que, segundo a tradição, foi bispo de Formia e da Campania e morreu martirizado na Grande Perseguição promovida por Diocleciano. Ele foi considerado protetor dos marinheiros, atributo que também foi associado a Pedro Gonçalves. Assim, o nome Ermo ou Elmo também foi vinculado ao santo hispano, que, com o tempo, passou a ser denominado como Pedro Gonçalves Telmo ou somente Telmo.

${ }^{21} \mathrm{O}$ culto a Pedro Gonçalves expandiu-se por várias regiões do mundo. Entretanto, ele não foi canonizado pelo papa.

${ }^{22} \mathrm{O}$ inquérito dos milagres e a missa foram traduzidos e publicados em 2019 pelas professoras Andréia

C. L. Frazão da Silva e Andrea Reis Ferreira Torres. Cf. bibliografia ao final.

${ }^{23}$ Esses argumentos, assim como outros, estão desenvolvidos de forma mais detida em Silva 2017a e $2017 b$.

${ }^{24}$ Como os já citados Vila, Fernandez Conde e Garcia de la Borbolla.

${ }^{25}$ Ainda que a obra tenha sido redigida total ou parcialmente em outro local por motivos técnicos, foi composta tendo como referencial a diocese de Tui.

${ }^{26}$ Detalhes sobre a datação e patrocínio da LBPG, cf.: SILVA, 2017a e b.

${ }^{27}$ Tivemos acesso ao manuscrito por meio de uma cópia digitalizada disponibilizada, gentilmente, pelo professor Suso Vila.

${ }^{28}$ Utilizamos aqui a divisão em leituras presente no manuscrito, seguida na tradução para português da obra.

${ }^{29}$ Como já ressaltado, a LBPG foi transmitida de forma incompleta. Como não tivemos acesso à cópia do século XVI, podemos supor que a Leitura 15 siga essa mesma lógica de divisão.

${ }^{30}$ Vale destacar que nessa organização das leituras por temas e/ou episódios há uma exceção, pois a 12 finaliza apresentando o início de um discurso proferido por Pedro para a multidão que o seguia e a 13 
inicia com a apresentação da segunda parte desse mesmo discurso, no qual o Frade anuncia sua morte. Contudo, vale salientar que, mesmo dividindo o discurso em duas leituras, cada uma delas mantém certa unidade, pois a 12 trata de milagres operados em vida e a 13 dos episódios que antecederam a morte do santo.

${ }^{31}$ Sobre o tema, cf. SÁNCHEZ-ROMATE, 1992: 6.

${ }^{32}$ Cf. Capítulos II, 8; III,1; VII, 1; IX, 3; disponíveis online em https://www.capuchinhos.org.br/ procasp/franciscanismo/fontes-biograficas/sao-boaventura/legenda-maior/capitulo-3. Acesso em 09/09/2019.

33 “(...) vasculum nequitiae omnique diabolica fallacia plena” (p.251).

${ }^{34}$ "Essa oferta é uma das falas em discurso direto da mulher: "O que prometeis dar-me quando fizer esse irmão cair, com uma concubina, no mesmo pecado que ele repreendeu tão duramente e censurou tantas vezes?" / "Quid igitur mihi dare promittitis, \& ego fratrem hunc veluti pellicem in idem peccatum ruere faciam, quod idem vos tam acriter reprehendens tantum ac toties detestatur?" (p.251).

35"Uma mulher pecadora que estava por perto, desejando dar prazer aos malvados e exercitar sua malícia próxima a ele" / "Quaedam peccatrix femina, quae aderat malevolis placere cupiens, aut suam circa eum malitiam exercere" (p.251).

36 “ (...) induzida pelos pedidos daqueles e também pelo valor”/ “(...) certa promissa sibi quantitate pecuniae si hoc perficeret, prece quoque illorum inducta" (p.251).

${ }^{37}$ Omitimos alguns detalhes que não são essenciais na análise.

${ }^{38}$ Esse anúncio, talvez para ganhar maior efeito narrativo, é registrado em discurso direto: “- Caríssima filha, sendo assim, eu não quero que por minha culpa sua vida se consuma tão perniciosa e cruelmente. Assim, pode esperar-me aqui, que vou preparar um leito para nós"/ "(...) Charissima filia, ex quo sic est, nec ego volo, ut per me vita tua tam pernitiose, tamque crudeliter extinguatur: me igitur hic expecta, \& ego vadens parabo lecticam nobis" (p.252).

39 “(...) cum esset quamquam non longus corpore, aspecto attamen placidus, naturalli suavis alloquio, hilaris face, ac adeo cuncta morum interior \& exteriori honestate compositus, ut omnium in eumaspicientium mox affectibus illaberetur" (p.253).

${ }^{40}$ Trata-se do episódio narrado em Daniel 3, no qual os jovens judeus Sadraque, Mesaque e Abednego são colocados em um forno ardente por ordem do Rei Nabucodonosor.

${ }^{41}$ Segundo a obra, ela afirma: "Com efeito, irmão Pedro, qualquer perigo que suceda a mim, também sucederá ao senhor, a quem reconheci como verdadeiro servo de Deus. Darei de boa vontade essa pequena quantidade de vinho"/“(...) Vere Frater Petre, quidquid periculi mihi accidat, vobis, quam ipsius Dei servum verum novi, vinum ipsum modicum grato animo propinabo " ( $\mathrm{p} .254)$.

${ }^{42}$ Na narrativa, ela declara: "Homem pecador, essa bebida não é para ti, não te apresses em prová-lo, pois foi conseguida de forma divina"/ "(...) peccator homo, potus hujusmodi pro te non est, nec ipsum gustare praesumas, cum divinitus sit procuratus" $"(\mathrm{p} .255)$.

43 “(...) Dña, justae petitioni vestrae vivens, vel difunctus satisfacere laborabo” (p.263).

${ }^{44}$ Como o último milagre não está preservado, não sabemos se a Senhora nobre também teve as suas falas registradas em discurso direto.

${ }^{45}$ Essa fala, uma queixa de um companheiro de viagem do frade, está registrada na Leitura 12.

${ }^{46}$ Ainda que o narrador insista, seguindo os topoi do gênero, que Pedro operou muitos milagres, incluindo a cura de diversas enfermidades, os milagres em vida relatados são: dois vinculados à manutenção de sua castidade, mencionados na análise; três estão relacionados à provisão alimentação, incluindo a multiplicação de vinho ressaltada; um trata-se da proteção da multidão que o seguia face a uma tempestade. Quanto aos milagres post-mortem, além do que foi transmitido incompleto, há o relato da emissão de um óleo do túmulo do santo. 